\title{
EKSISTENSI BAHASA ARAB DALAM DUNIA DAKWAH
}

\author{
Besse Wahida
}

\begin{abstract}
Abstrak
Dakwah merupakan suatu bentuk komunikasi keagamaan yang tujuan utamanya adalah amar ma'ruf dan nahi munkar dengan objek dakwah, mad'u, baik berupa individu maupun kelompok. Da'i sebagai pelaku dakwah dituntut untuk menguasai materi dakwah yang akan disampaikan kepada mad'unya, yang mana mencakup masalah aqidah, syariah, muamalah, dan akhlaq. Adapun yang menjadi sumber dari materi dakwah yaitu Alquran dan hadis yang merupakan sumber ajaran dan sumber hukum Islam yang tertinggi. Eksistensi bahasa Arab dalam dakwah menjadi begitu penting karena kedua sumber materi dakwah tersebut menggunakan bahasa Arab, sehingga bahasa Arab menjadi kunci pembuka bagi ilmu pengetahuan keislaman. Untuk mengkaji dan mendalaminya dibutuhkan pula penguasaan terhadap berbagai cabang ilmu seperti IImu Tafsir, IImu Nahwu, IImu Bayan, Ushul Fiqih, dll., yang tidak jauh dari bahasa Arab. Selain itu, bukubuku literatur asli yang merupakan hasil pemikiran, penafsiran, syarahan terhadap Alqur'an dan hadis oleh para ulama-ulama masa lalu tertulis dalam bahasa Arab yang kesemuanya itu merupakan bagian dari sumber materi dakwah yang harusnya diketahui oleh para da'i. Semua itu bertujuan agar dalam penyampaian materi dakwah yang bersumber dari Alquran maupun hadis sesuai dengan syariat Islam dan menjauhkan dari kesalahpahaman pemahaman yang diterima si mad'u dalam menerima pesan-pesan yang disampaikan oleh seorang da'i.
\end{abstract}

Kata Kunci: Islam, Alquran, Bahasa Arab dan Dakwah

\section{A. Pendahuluan}

Bahasa merupakan sesuatu yang tidak pernah terpisahkan dari kehidupan manusia karena bahasa adalah dasar yang pertama-tama dan paling berurat akar dari kehidupan manusia. Bahasa adalah alat yang dipergunakan untuk membentuk pikiran, perasaan, keinginan, dan perbuatan-perbuatan manusia, alat yang dipakai untuk mempengaruhi dan dipengaruhi. Bahasa adalah tanda yang jelas dari kepribadian yang baik maupun yang buruk, tanda yang jelas dari keluarga dan bangsa, tanda yang jelas dari budi kemanusiaan (Hasyim Asy'ariy, 1999:3). Bahasa merupakan perkataan- 
perkataan baik dalam bentuk lisan maupun tulisan. Bahasa menjadi alat komunikasi bagi manusia yang digunakan untuk mengaktualisasikan dirinya, alat untuk menyampaikan segala kebutuhannya, dan untuk berpikir.

$$
\text { Syaiful Bahri Djamarah }
$$

mengatakan bahwa bahasa merupakan sarana yang efektif untuk menjalin komunikasi sosial. Tanpa bahasa, komunikasi tidak akan dapat dilakukan dengan baik dan interaksi sosial pun tidak akan pernah terjadi, karena hanya dengan bahasa seseorang dapat menyampaikan maksudnya kepada orang lain (Syaiful Bahri Djamarah, 2008:46).

Di samping sebagai alat komunikasi, bahasa juga merupakan alat untuk memperoleh berbagai macam pengetahuan. Diibaratkan sebagai rumah, bahasa ini merupakan kunci utama. Dengan memegang kunci utama rumah, berarti seseorang dapat membuka isi rumah tersebut. Begitupula dengan bahasa, manusia mampu membuka jendela untuk meneropong sejuta pengetahuan yang terhampar di alam semesta ini.

Begitu pentingnya bahasa, sehingga seseorang yang tidak mengenal bahasa akan merasa asing dan tenggelam dalam keasingan dan kebodohan. Ketidaktahuannya akan bahasa akan berpotensi membangun kekerdilannya sendiri. Oleh karena itu, alternatif yang sangat mungkin dimunculkan adalah dengan mempelajari bahasa itu sendiri.

Bahasa Arab sebagai media dalam berkomunikasi merupakan bahasa yang digunakan oleh banyak kelompok manusia dan menjadi salah satu bahasa mayor di dunia (Sabah Ghazzawi, 1992:1) yang saat ini digunakan oleh hampir seluruh belahan dunia, baik itu penutur asli dalam hal ini belahan dunia timur khususnya negara-negara Arab dan Afrika, maupun yang bukan penutur asli. Bahasa Arab sudah menjadi bahasa dunia internasional yang digunakan dalam forum resmi dunia seperti, PBB, OKI, dan Liga Arab.

Sejak bahasa Arab yang tertuang di dalam Alquran didengungkan hingga kini, semua pengamat baik dari dunia Arab maupun dari barat menganggapnya sebagai bahasa yang memiliki standar ketinggian dan keelokan linguistik tertinggi yang tiada taranya. Ali al-Najjar dalam Syahin mengungkapkan bahwa bahasa Arab merupakan bahasa yang terluas dan terkaya kandungannya, deskripsi dan pemaparannya sangat detail. (Syahin, 1980:35).

Selanjutnya Akkawi (1987:2) menulis bahwa Amir al-Mu'minin Umar bin al-Khattab r.a. berkata: hendaklah kamu sekalian tamak mempelajari bahasa 
Arab karena bahasa Arab itu merupakan bahagian dari agamamu. Atas dasar ini pula lah Abdul Alim Ibrahim (1978:48) berkata bahwa bahasa Arab merupakan bahasa orang Arab dan sekaligus juga merupakan bahasa agama Islam. Meskipun menurut Nurcholis Majid dalam Azhar Arsyad bahwa bahasa Arab bukanlah bahasa khusus orang muslim dan agama Islam semata, melainkan juga bahasa kaum non-muslim dan agama bukan Islam seperti Yahudi dan Kristen karena minoritas-minoritas Arab bukan muslim masih ada dijumpai di beberapa negara Arab kecuali dikawasan Arab Saudi, khususnya Makkah-Madinah (Azhar Arsyad, 2004:xiv).

Namun dapat dipahami bahwa kesan bahasa Arab adalah bahasa agama Islam disebabkan oleh keberadaan bahasa Arab yang lebih dominan dari pada bahasa-bahasa lainnya dalam penggunaannya baik dalam bentuk tulisan maupun lisan.

Sehingga tidaklah keliru jika dikatakan bahwa orang-orang yang hendak memahami hukum-hukum atau ajaran-ajaran agama Islam dengan baik haruslah berusaha mempelajari bahasa Arab. Bahasa-bahasa lain, termasuk bahasa Indonesia tidak dapat diandalkan untuk memberikan kepastian arti yang tersurat dan tersirat dari makna yang terkandung dalam Alquran. (Ash-Shiddiqi, 1975: 207).

Sehubungan dengan itu, bahasa Arab juga menjadi bahasa yang tidak terpisahkan dari dunia dakwah. Bagaimana tidak, kata dakwah sendiri barasal dari bahasa Arab yaitu da'a, yad'u, da'watan yang mengandung makna memanggil, menyeru, mengajak dan memohon atau meminta (Jum'ah, 2014:24). Selanjutnya, dakwah yang merupakan bentuk ajakan dan seruan kepada yang ma'ruf dan mencegah dari yang munkar tentu saja menggunakan Alquran dan hadis sebagai sumber ajaran Islam dan dasar panutan yang mana keduanya menggunakan bahasa Arab.

Aktivitas dakwah merupakan suatu kegiatan komunikasi yang inti tujuannya adalah mempengaruhi orang lain ke arah yang baik. Setiap individu muslim dianggap sebagai komunikator agama atau da'i dimana diwajibkan menyampaikan ajaran agama sesuai kadar kemampuan masing-masing individu. Tanggung jawab ini menjadi suatu tugas yang penting, sehingga Rasulullah SAW dalam salah satu haditsnya yang sangat populer mengatakan yaitu,” بلغو أبني و لو أية " menuntut setiap muslim menyampaikan sesuatu darinya walaupun hanya "satu ayat". Simbolik walau hanya satu ayat 
menunjukkan pentingnya kebenaran ajaran agama disampaikan dengan baik.

Pesan dakwah yang disampaikan oleh setiap individu tentu saja membutuhkan dalil-dalil nash yang mendukung dan menjadi penguat sehingga apa yang disampaikan oleh seorang da'i kepada pendengarnya atau mad'u menjadi lebih meyakinkan. Dalildalil nash tersebut adalah Alquran dan hadis yang jika ingin dikaji dan dipahami harus menggunakan bahasa Arab. Sehingga bahasa Arab dan dakwah merupakan suatu hal yang tidak bisa dipisahkan karena keduanya merupakan sendi agama Islam. Adanya hubungan antara kedua hal tersebut melatarbelakangi penulisan makalah ini.

Adapun yang menjadi pokok pembahasan dalam makalah ini yaitu, eksistensi bahasa Arab dalam Islam, Bahasa arab sebagai bahasa Alquran, dan posisi bahasa Arab dalam dakwah.

\section{B. Pembahasan}

\section{Bahasa Arab dan Islam}

Sebagai bahasa yang hidup, bahasa Arab, baik klasik maupun modern memiliki peranan yang sangat penting dalam agama Islam. Sebagaimana diketahui, Islam adalah agama wahyu yang diturunkan kepada nabi Muhammad SAW, sebagai utusan terakhir dengan perantaraan malaikat jibril. Wahyu yang diturunkan kepada nabi Muhammad SAW yang menggunakan bahasa Arab dihimpun menjadi kitab suci Alquran. Begitu pula hadis yang merupakan penjelasan dan penafsiran Alquran dihimpun dan disusun dalam bahasa Arab. Kedua sumber pokok ajaran agama Islam tersebut berbahasa Arab (Ahmad Izzan, 2007:53).

Dalam sejarah perkembangan agama samawi atau agama wahyu, tidak terdapat kitab suci yang masih asli bahasanya, kecuali Alquran. Ayatayat Alquran yang diturunkan dalam dua periode, yaitu sebelum hijrah ke madinah dan setelah hijrah, masih tetap utuh dalam bahasa aslinya. Keaslian atau otentisitas Alquran ini merupakan mukjizat sebagaimana yang Allah SWT janjikan (Ahmad Izzan, 2007:53). Bahasa Arab juga adalah bahasa Nabi Muhammad SAW dan bahasa verbal para sahabat. Hadis-hadis Nabi yang sampai kepada kita menggunakan bahasa Arab. Oleh karena itu, penguasaan bahasa Arab menjadi pintu gerbang dalam memahami Alquran dan hadis dan dapat dikatakan bahwa mempelajari bahasa Arab merupakan suatu kebutuhan yang utama guna mempelajari dan memperdalam 
pemahaman ajaran Islam dari sumber aslinya.

Seiring dengan timbulnya berbagai masalah keagamaan setelah nabi Muhammad SAW wafat, dan setelah periode khulafa ar-Rasyidin, timbullah peran ulama yang berjasa dalam usaha-usaha memahami dan mensosialisasikan syariah, baik yang berkenan dengan ibadah muamalah maupun jinayah. Dengan demikian selain bersumber pada Alquran dan hadis dalam penetapan hukum, ulama juga menambahkan sumber hukum lain yang dikembangkan dari hasil ijtihad pemikiran mereka yang berdasarkan Alquran dan hadis, yaitu ijma', qiyas, mashlahat murshalah dan istihsan. Uraian dan pembahasan mengenai sumber hukum tersebut banyak ditulis ulama terdahulu dalam kitab-kitab klasik yang berbahasa Arab.

Bahasa Arab selain sebagai bahasa lisan, ia juga bahasa tulisan. Bahasa tulisan inilah yang telah membangun tradisi ilmiah di kalangan umat Islam. Secara historis dapat dibuktikan melalui karya-karya fenomental ulama-ulama di berbagai bidang; di bidang tafsir dikenal karya tulis hasil kajian ulama semacam Abdullah Ibnu Abbas dengan kitabnya Tafsir Ibnu Abbas, Abu Ja'far Muhammad bin Jarir al-Thabarani dengan karyanya
Tafsir Jami'at al-Bayan fi Tafsir Alquran, Abu al-Qosim Muhammad bin Umar alZamakhsari dengan tafsirnya al-Kasysyaf, Rasyid Ridho dengan tafsirnya al- Manar, Thanthawi Jauhari dengan tafsirnya Tafsir Jawahir dan banyak lagi yang lain-lain, semuanya tertulis dalam bahasa Arab. Demikian juga dalam bidang hadits, alJami' al-Shahih karya Imam Bukhari, alJami' al-Shahih karya Imam Muslim, alSunan Abu Daud karya Abu Daud, alSunan Ibnu Majah karya Ibnu Majah (Atang Abd. Hakim dan Jauih Mubarak, 2008:81) dan di bidang ilmu-ilmu keislaman yang lainnya, tertulis dalam bahasa Arab. Karena sumber-sumber asli ajaran Islam dan ilmu-ilmu keislaman adalah bahasa Arab, maka sangatlah penting bagi umat Islam terutama kalangan ilmuannya untuk mempelajari dan memahami serta menguasai bahasa Arab.

Bahasa Arab dalam kajian Islam menjadi menarik dan penting, disebabkan bahwa sumber asli ajaran Islam Alquran dan hadis ditulis dalam bahasa Arab, kitab-kitab karya ulama-ulama besar yang mempengaruhi alur pemikiran umat Islam terutama di bidang tafsir, hadits, fiqih, aqidah, tasawuf ditulis dalam bahasa Arab, dan kajian ilmu keislaman akan semakin berbobot jika mengambil rujukan dari bahasa Arab. 
Selanjutnya, penggunaan bahasa Arab yang sangat fenomenal dalam agama tampak jelas dalam pelaksanaan ibadah ritual seperti ungkapan untuk memanggil atau mengajak shalat yang disebut azan dam iqamat. Selain itu, bacaan-bacaan yang diucapkan dilafazkan dalam shalat pun harus menggunakan bahasa Arab sesuai dengan tuntunan nabi Muhammad SAW. Dengan demikian, tidaklah salah jika ada yang mengatakan bahwa bahasa Arab adalah bahasa agama Islam.

Di sisi lain, para serjana, baik di barat maupun di timur, yang mengkaji dan terus mendalami pertumbuhan dan perkembangan agama Islam dan bahkan IImu pengetahuan tidak akan bisa melepaskan diri dari kebutuhan akan bahasa Arab. Hal tersebut dapat dilihat dalam sejarah dimana buku-buku literatur filsafat, ilmu pengetahuan dan sain yang sudah diterjemahkan dari bahasa Yunani kuno ke dalam bahasa Arab dan diinterpretasi atau ditafsirkan oleh para ilmuan Islam pada tahun 750-1258M telah menjadi referensi utama bagi dunia barat dalam mengembangkan ilmu pengetahuan (Ahmad Izza, 2007: 56).

Dari pemaparan di atas, nampak jelas bahwa eksistensi bahasa Arab dalam dunia Islam begitu penting karena bahasa Arab merupakan bahasa kunci ajaran-ajaran Islam yang tertuang dalam Alquran, hadis, dan kitab-kitab tafsir, dan syarah hadis. Selain itu bahasa Arab juga menjadi bahasa kunci pembuka khasanah ilmu pengetahuan agama dan sains yang sumber utamanya terdapat dalam kitab-kitab berbahasa Arab yang banyak dikaji oleh para ilmuwan barat.

\section{Bahasa Arab dan Alquran}

Alquran adalah wahyu Islam dan Islam adalah agama Allah yang diturunkan kepada umat manusia. Pengetahuan mengenai pokok-pokok ajaran Islam yang tertuang seluruhnya dalam Alquran tidak akan bisa dipahami dengan baik kecuali dengan bahasanya. Sehingga orang-orang bangsa lain dengan bahasa selain bahasa Alquran dituntut juga untuk memahami bahasa Alquran dengan cara menerjemahkannya.

Bahasa Arab, salah satu bahasa di dunia, merupakan bahasa yang sangat penting karena terpilih menjadi bahasa Alquran yang dianggap sebagai kitab suci yang lengkap dan sempurna. Alquran adalah sebuah Teks yang mengatasi dan melampaui teks-teks lain dalam sejarah karena Alquran merupakan wahyu yang diturunkan Allah melalui malaikatnya kepada ummat manusia. Ruh keilahian 
Alquran-lah yang membuatnya tahan dari pelbagai kritik dan gempuran (Nasr Hamid Abu Zaid, 2002:1). Eksistensi bahasa Arab sebagai bahasa Alquran disebutkan Allah SAW dalam Surah Yusuf ayat 2:

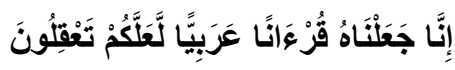

Artinya: Sesungguhnya Kami telah menjadikan Al Quran dalam bahasa Arab, supaya kalian berpikir.

Ibnu katsir berkata ketika menafsirkan surat Yusuf ayat 2 di atas: "Yang demikian itu (bahwa Al -Qur'an diturunkan dalam bahasa Arab) karena bahasa Arab adalah bahasa yang paling fasih, jelas, luas, dan maknanya lebih mengena lagi cocok untuk jiwa manusia. Oleh karena itu, kitab yang paling mulia (yaitu Alquran) diturunkan kepada rasul yang paling mulia (yaitu: Rosulullah), dengan bahasa yang termulia (yaitu Bahasa Arab), melalui perantara malaikat yang paling mulia (yaitu malaikat Jibril), ditambah kitab ini pun diturunkan pada dataran yang paling mulia diatas muka bumi (yaitu tanah Arab), serta awal turunnya pun pada bulan yang paling mulia (yaitu Ramadhan), sehingga Alquran menjadi sempurna dari segala sisi." (Tafsir Alquran Ibnu Katsir, Jilid 2: 613).

Alquran sebagai wahyu memiliki keistimewaan yang tak terbilang, diantaranya adalah bahwa Alquran yang notabene berbahasa Arab memiliki kaidah bahasa yang fasih dan mengandung gaya bahasa, uslub dan tarkib kalimat yang tak tertandingi oleh penyair atau pengarang dari manapun sepanjang zaman. Hal ini ditegaskan Allah dalam firmannya Q.S. Al Baqarah ayat 23 yang artinya "Dan jika kamu (tetap) dalam keraguan tentang Al Quran yang kami wahyukan kepada hamba kami (Muhammad), buatlah satu surat (saja) yang semisal Al Quran itu dan ajaklah penolongpenolongmu selain Allah, jika kamu orang-orang yang benar".

Setidaknya, ada tiga fungsi dan tujuan mengapa Alquran diturunkan dalam bahasa Arab. Fungsi dan tujuan itu sekaligus merupakan keunggulan dan keutamaannya menurut Alquran. Fungsi tersebut yaitu:

\section{a. Berfungsi sebagai Sumber Informasi dan Sumber IImu}

Allah berfirman dalam Q.S. AlFushshilat, 41:2-3 yang artinya "Alquran ini diturunkan dari Zat Yang Maha Rahman dan Rahim, Kitab yang dijelaskan ayat-ayatnya sebagai Alquran yang berbahasa Arab, bagi kaum yang mengetahui. Selain itu, terdapat firman Allah SAW dalam Q.S Al-Nahl, 16: 103 yang artinya “... sesungguhnya Alquran itu diajarkan 
oleh seorang manusia kepadanya (Muhammad). Bahasa orang yang mereka tuduhkan (bahwa Muhammad belajar) kepadanya adalah bahasa Ajam. Padahal ini (Alquran) adalah dalam bahasa Arab yan jelas.

Kata mengetahui dalam surah alfushshilat menunjukkan penegasan fungsi dan tujuan diturunkannya Alquran dalam bahasa Arab. Dalam redaksi Arabnya adalah ya'lamuun, yang artinya mengetahui. Alquran adalah Kitab Suci yang mengandung ilmu-ilmu yang tak terbatas, dan takkan bisa digali secara tuntas. IImu yang dikandungnya takkan pernah habis walau terus digali dan dikuras sepanjang masa, sepanjang kehidupan dunia masih ada. Alquran adalah sumber ilmu yang kaya dan abadi.

Menariknya, penegasan bahwa Alquran sebagai sumber ilmu (ya`amuun) itu, bukan sosok Alqurannya saja. Melainkan sosok Alquran yang berbahasa arab dengan lafaz Qur'aanan ‘Arabiyyan. Sifat kearaban itu melekat dalam Alquran. Seperti pula yang disebutkan dalam surah an-Nahl dengan arabiyyun mubin yang menyanggah dan membantah anggapan yang mengatakan bahwa bahasa Alquran adalah bahasa orang Ajam tetapi merupakan bahasa Arab yang jelas.

Ini artinya, yang menjadi sumber ilmu itu bukan Alquran yang Kitab Suci itu, tetapi juga bahasa Arab yang menjadi media kitab suci itu diturunkan. Alquran mewujud menjadi sumber ilmu ketika ia diturunkan dalam bahasa Arab. Ketika Alquran menjadi sumer ilmu, maka bahasa Arab juga menjadi sumber ilmu. Sebuah kitab suci yang menjadi sumber ilmu hanya pantas diturunkan dalam sebuah bahasa yang memang pantas menjadi sumber ilmu pula. Sehingga ada kompatibilitas (kesetimbangan) antara kitab suci dan bahasa yang menjadi medianya. Dan kompatibilitas itu takkan terjadi bila medianya menggunakan bahasa selain Arab. Dengan demikian, dengan sendirinya berarti bahasa Arab adalah sebuah bahasa yang kaya ilmu, menjadi sumber informasi dan pengetahuan. (M.Anwar, Artikel Abatasa)

\section{b. Berfungsi Inteligensi, Mencerdaskan}

Ada dua ayat yang menegaskan ini. Yaitu: firman Allah SAW dalam Q.S Yusuf,12: 1-2. Yang artinya "Itu adalah ayat-ayat Al-Kitab yang jelas. Sesungguhnya Kami telah menurunkan Al-Kitab itu Alquran yang 
Berbahasa Arab agar kalian berakal. Dan Q.S. al-Zukhruf, 43:1-3 yang artinya "Demi Al-Kitab yang jelas. Sesungguhnya Kami telah menjadikan Al-Kitab itu Alquran yang Berbahasa Arab agar kalian berakal. Di situ Allah SWT. menegaskan bahwa tujuan diturunkan dan dijadikannya Alquran berbahasa Arab adalah "agar kalian berakal" (la`allakum ta qiluun). Kata aqal dalam Alquran selalu digunakan dalam bentuk kata kerja, kata yang bermakna aktivitas yang terus berproses. Akal bermakna kecerdasan. Sehingga, mengapa Alquran diturunkan berbahasa Arab, di antaranya adalah agar kita cerdas.

Itu artinya, kearaban Alquran itu berfungsi mencerdaskan para pembaca dan pengkajinya. Yang mencerdaskan manusia itu bukan saja Alquran sebagai kitab sucinya, melainkan juga Alquran yang berbahasa Arabnya juga. Karena sifat kearaban itu melekat dalam Alquran, maka ketika Alquran mencerdaskan, maka bahasa Arab yang menjadi medianya juga, mencerdaskan.

Adapun yang perlu diteliti lebih lanjut adalah, dalam kedua ayat di atas, Allah mengungkapkan dua kata yang berbeda, berkaitan dengan Alquran berbahasa Arab itu. Pertama Dia mengungkapkan, "Kami menurunkan". Dan yang kedua Dia mengungkapkan, "Kami menjadikan" Antara kata menurunkan dan menjadikan, tentu saja keduanya memiliki makna yang berbeda.

"Menurunkan" adalah sebuah aktivitas menggerakkan sesuatu dari atas ke bawah. Artinya, Alquran diturunkan dari Alam Tinggi (Lawh Mahfuzh) ke Alam Rendah (alam dunia), dengan bahasa Arab. Sedangkan "menjadikan" adalah sebuah tindakan menetapkan dan mengadakan sesuatu dari yang tidak ada menjadi ada, atau dari suatu kondisi ke kondisi lain yang dikehendaki. Ini berarti, bahwa kearaban Alquran adalah sebuah ketetapan yang Allah kehendaki. (M.Anwar, Artikel Abatasa).

c. Fungi Spritual

Dalam Alquran Q.S. Al-Zumar, 39: ayat 27-28 yang artinya "dan sungguh telah kami buatkan dalam Alquran ini segala macam perumpamaan bagi manusia agar mereka dapat pelajaran, yaitu Alquran dalam bahasa Arab tidak ada kebengkokan (di dalamnya) agar mereka bertakwa.

Di sini ditegaskan bahwa Alquran berbahasa itu tujuannya adalah agar 
kita semua bertakwa. Tentu saja takwa merupakan sebuah konsep yang sangat luas dan dalam. Tetapi secara garis besar, takwa merupakan dimensi spiritualitas.

Secara implisit ini menyatakan bahwa Alquran yang berbahasa Arab itu bisa menjadikan seseorang bertakwa, menjadi baik, menjadi sosok yang spiritual, yang dekat kepada Tuhan. Banyak kalangan yang menceritakan pengalaman mereka, bahwa ketika mereka membaca Alquran mereka merasa damai, tenang, dan merasa dekat dengan Rabb. Bunyi dan nada bacaan Alquran membuat mereka hanyut dalam kedamaian.

Itu artinya, Alquran dapat menggerakkan orang untuk menspiritualkan dirinya, untuk menjadi sosok yang mulia dan dekat dengan Penguasa dirinya. Alquran dapat menumbuhkan dan mengaktifkan kekuatan pengendalian diri pada seseorang. Alquran memiliki kekuatan untuk mendamaikan dan menenangkan. Dan kekuatan itu muncul dari Alquran yang berbahasa Arab.

Ini juga sekaligus berarti bahwa bahasa Arab memang memiliki kekuatan untuk menspiritualkan manusia, membuat manusia cenderung pada kebaikan. Berbeda dengan bahasa-bahasa lain. Kita misalnya dapat merasakan dan menyaksikan, jika ada orang yang pandai berbahasa Arab, maka ia akan lazim disebut oleh masyarakatnya dengan sebutan ustadz atau bahkan kyai. Ketika seseorang sudah dilabeli sebutan ustadz, maka ia akan berpikir seribu kali untuk bertindak buruk atau amoral. Sehingga, bahasa Arab telah menjadikannya bergerak pada kebaikan. Bahasa Arab adalah bahasa dakwah, bahasa yang dapat memperbaiki perilaku seseorang. Sebaliknya, kita juga dapat merasakan, ada sebuah bahasa yang auranya justru mendorong seseorang pada keburukan dan kemaksiatan. (M.Anwar, Artikel Abatasa)

Dari penjelasan di atas, nampak jelas bahwa pada dasarnya Allah menurunkan Alquran dalam bahasa Arab bukanlah merupakan suatu hal yang kebetulan. Bahasa Arab merupakan bahasa yang strategis yang jika dilihat secara geografis, wilayah Arab terletak di tengah-tengah sehingga menjadi sentral, selain itu tentu saja karena bahasa Arab memiliki kekayaan kosa kata dan keseksamaan.

Amatlah sulit kalau suatu wahyu untuk nabi penghabisan diturunkan di 
lingkungan masyarakat yang bahasanya tidak memadai untuk merekam wahyu yang yang mencakup perbendaharaan kata filsafat, iman, hukum, kemasyarakatan, sejarah, politik dan lain lain. Kata-kata wahyu seyogyanya seksama tepat, tidak boleh tertukar baik dalam kekhasan dan maupun dalam keumumannya. (Azhar Arsyad, 2004)

Kata Hur (Alquran, 37: 49, 44:54, $52: 20$, 55:72, dan 56:22) telah diterjemahkan sebagai bidadari. Ini merupakan vulgarisasi yang agak serampangan. Kata hur adalah jamak dari ahwar (L) dan haura (P), keduanya berasal dari kata hawar, yakni kejelian mata (yang hitam sangat hitam dan yang putih sangat putih). Hur dalam konsep pemikiran Alquran adalah makhluk suci yang bukan merupakan objek pemuasan syahwat seperti bidadari (dari bahasa Sanskrit Vidyadari). Dalam konsep Hinduisme Vidyadari adalah obyek pemuasan syahwat dewa dan manusia yang masuk ke svargalokha.

Al-jannah di dalam Alquran memiliki arti yang tidak sama dengan svarga Hindu. Secara harfiah svarga sama dengan al-firdaus, paradiso, tetapi secara konseptual firdaus Islam tidaklah sama dengan svarga Hindu, dimana penghuni svarga dapat memuaskan nafsunya, sedangkan dalam konsep Islam kehidupan ahl aljannah telah mencapai kesempurnaan rohani, nafsunya telah muthmainnah (Poeradisastra, 1981).

Disinilah pengetahuan bahasa Arab memegang peranan yang sangat penting untuk memahami ajaranajaran agama Islam guna ditransfer ke benak masyarakat. Sehingga mampu memberikan pemahaman yang benar dan tepat terhadap kandungan Alquran dan hadis sebagai sumber ajaran dan hukum Islam.

\section{Posisi Bahasa Arab dalam Dakwah}

Dakwah merupakan salah satu bentuk komunikasi dan seluruh agama disebarluaskan melalui proses komunikasi. Tanpa adanya komunikasi agama tidak mungkin bisa berkembang di dunia ini. Hal ini berlaku bagi semua agama di dunia, tak terkecuali agama Islam. Proses komunikasi dalam penyebaran agama Islam diistilahkan dengan dakwah.

Dakwah adalah suatu kajian dalam seruan, baik dengan lisan, tulisan, atau tingkah laku yang dilakukan secara sadar dan berencana untuk mempengaruhi orang lain agar timbul suatu pengertian, kesadaran, penghayatan, serta pengalaman 
ajaran agama tanpa adanya unsur paksaan (M. Arifin, 1993:6). Dakwah merupakan upaya untuk menumbuhkan kecenderungan dan ketertarikan dan tidak hanya terbatas pada aktivitas lisan semata akan tetapi mencakup seluruh aktivitas lisan maupun perbuatan yang ditunjukkan dalam rangka menunbuhkan kecenderungan dan ketertarikan dalam Islam. Artinya tujuan dakwah adalah bagaimana mengajak orang lain agar senantiasa mengamalkan apa yang diperintahkan oleh Allah SWT yang timbul dari kemauan mereka sendiri (Ahmad Mubarak, 2002:13).

Keberhasilan dakwah sangat bergantung pada kedekatan juru dakwah dengan umatnya. Juru dakwah yang terlahir pada suatu lingkungan pasti akan memahami lorong-lorong kesesatan yang membungkus masyarakat di lingkungan tersebut.

Selain pengetahuan yang dalam mengenai kondisi dari lingkungannya, juru dakwah juga harus bisa berkomunikasi dengan masyarakatnya dengan baik. Tentunya yang dibutuhkan oleh juru dakwah adalah penguasaan bahasa yang digunakan untuk komunikasi sehari-hari.
Adapun unsur-unsur dakwah meliputi: da'i, mad'u, dan materi dakwah.

a. Da'i secara bahasa berasal dari bahasa Arab, bentuk isim fa'il dari da'a, yad'u, da'watan yang berarti orang yang melakukan dakwah. Secara terminologi, da'l berarti setiap muslim yang mukallaf (aqi bhalig) dengan kewajiban dakwah (Idris A Shomad, 2004:6). Seorang da'i tidak hanya harus mengetahui dan hafal berbagai macam ayat dan hadis melainkan seorang da'i dituntut harus menguasai ajaranajaran Islam. Penuh kewibawaan dan wawasan yang tinggi karena selayaknya da'i memahami berbagai aspek sendi kehidupan.

b. Mad'u yaitu manusia yang menjadi sasaran dakwah, atau manusia penerima dakwah, baik individu maupun kelompok, baik beragama Islam maupun tidak, atau dengan kata lain, manusia secara keseluruhan (M. Munir dan Wahyu Ilahi:23). Mad'u juga dapat diartikan objek dakwah yang sedang dilakukan oleh seorang da'i.

c. Maddah atau materi dakwah adalah masalah isi pesan atau materi yang disampaiakan oleh da'i kepada mad'u yang bersumber dari Alquran dan hadis yang meliputi aqidah, 
syariah dan akhlaq (Nurul

Badrutamam, 2005:109). Yang perlu dipahami bahwa dakwah bukan hanya berkaitan dengan eksistensi dan wujud Allah, akan tetapi lebih dari itu, bagaimana memberikan kesadaran yang dalam agar mad'u dapat mengaktualisasikan aqidah, syariah dan akhlaq dalam kehidupan sehari-hari.

Seorang da'i harus mampu membaca kondisi dan situasi mad'u agar materi yang diisampaikan mudah dipahami dan dilakksanakan oleh mad'u. Disinilah peran maddah atau materi sangat diutuhkan guna menunjang keberhasilan dalam berdakwah.

Adapun menurut M.Munir dan Wahyu, secara umum materi dakwah dapat diklasifikasikan menjadi empat masalah pokok, yaitu: 1) Masalah aqidah islamiyah atau keimanan. Aspek aqidah ini membentuk moral manusia. Karena aqidah bersifat sentral pada diri manusia dan sangat erat hubungannya dengan rukun iman. 2) Masalah syariah dan hukum. Hukum dan syariah disebut sebagai cermin peradaban. Materi dakwah yang meyajikan unsur syariah harus dapat menggambarkan atau memberikan informasi yang jelas di bidang hukum dalam bentuk status hukum yang bersifat wajib, mubah, makruh, dan haram. 3) Masalah muamalah. Islam merupakan agama yang melakukan urusan muamalah yang lebih besar porsinya dari urusan ibadah. Islam lebih banyak memperhatikan aspek kehidupan sosial daripada aspek kehidupan ritual. 4) Masalah akhlaq. Islam mengajarkan manusia berbuat baik dengan ukuran yang bersumber dari Allah. Sebagaimana telah diaktualisasikan oleh rasulullah SAW. Apa yang digariskan baik oleh-Nya dapat dipastikan baik secara esensial oleh akal pikiran manusia. Dalam Alquran dikemukakan bahwa kriteria baik itu antara lan bertumpu pada sifat-sifat Allah SWT. (M.Munir dan Wahyu Ilahi: 24-30)

Keberadaan bahasa Arab dalam dunia dakwah dapat dilihat dari sisi materi dakwah itu sendiri. Tentu saja ketika seorang da'l ingin menyampaikan suatu pesan keislaman yang menjadi materi dakwah harus lebih dahulu menguasai materi tersebut yang berasalkan dari Alquran maupun hadis yang berbahasakan bahasa Arab. Itu tentu saja seorang da'i harus menguasai terlebih dahulu 
bahasa Arab dan segala permasalahannya.

Seperti contoh, dalam mempelajari atau mendalami materi dakwah yang bersumberkan dari Alquran seorang da'i diharuskan menguasai metode - metode mempelajari ayat-ayat Alquran seperti IImu Tafsir, Ilmu Nahwu, Ilmu Bayan, Ushul Fiqih, dll., yang semua itu tidak terlepas dari bahasa Arab. Belum lagi adanya istilah-istilah keislaman yang tak jauh dari bahasa Arab. Dan kurang lebih seperti itu juga ketika seorang da'i ingin mempelajari hadis-hadis atau sunnah Rasulullah sebagai sumber dari materi dakwah.

Semua itu bertujuan agar dalam penyampaian materi dakwah yang bersumber dari Alquran maupun hadis sesuai dengan syariat Islam dan menjauhkan dari kesalahpahaman pemahaman yang diterima si Mad'u dalam menerima pesan-pesan yang disampaikan oleh seorang da'i.

Bahasa arab pun dapat menjadi seni ketika seorang da'i dalam menyampaikan pesan-pesan keIslamannya. Kredibilitas tidak tumbuh dengan sendirinya ia harus dibina atau dipupuk. Kredibilitas erat kaitannya dengan kharisma, dengan demikian kredibilitas dapat ditingkatkan sampai batas optimal.
Untuk mendapatkannya tersebut salah satu yang harus dimiliki seorang da'i adalah kemampuan menguasai bahasa, dan salah satu nya adalah bahasa Arab. Untuk memudahkan penyampaian dan memperindah retorika saat menyampaikan pesanpesan keislaman.

\section{Penutup}

Untuk menyimpulkan uraian tentang eksistensi bahasa Arab dalam dunia dakwah maka dapat dikemukakan hal-hal sebagai berikut:

1. Bahasa Arab secara kenyataan bukanlah bahasa khusus orang-orang muslim dan bukan satu-satunya bahasa agama Islam, tetapi bahasa Arab adalah bahasa yang paling dominan digunakan dalam Islam karena kaitannya dengan keberadaan Muhammad sebagai orang Arab dan Alquran yang diturunkan dalam bahasa Arab.

2. Bahasa arab adalah bahasa Alquran yang merupakan kitab suci agama Islam, dan merupakan sumber ajaran dan hukum Islam. Untuk memahami dan mengkaji isi dan kandungan Alquran dibutuhkan berbagai macam ilmu-ilmu yang berhubungan dengannya, seperti berbagai cabang ilmu tafsir, ushul figh, Nahwu, 
Balaghah, dll., yang kesemuanya itu tidak terlepas dari bahasa Arab.

3. Sementara dakwah merupakan salah satu bentuk komunikasi, dan seluruh agama disebarluaskan melalui komunikasi. Tujuan dakwah yaitu mengajak manusia ke jalan Allah SWT, jalan yang benar dan mengamalkan ajaran-ajaran Islam yang bersumber dari Alquran dan hadis. Keduanya merupakan sumber materi dakwah dan yang dapat dengan mudah dipahami dan dikaji dengan menggunakan bahasa Arab yang merupakan bahasa dari kedunya.

\section{Daftar Pustaka}

Asy'ariy, Hasyim. 1999. Bahasa Arab dan perkembangan ilmu pengetahuan, Jurnal Nadi. Edisi September, Malang.

Ghazzawi, Sabah. The Arabic language. Washington D.C. Center for Contemporary Arab Studies.

Taufiq, Muhammad Syahin. 1980. Awaamil Tanmiyyah al-Lugah alA'rabiyyah. Al-Qaahirah. Mathba'alDa'wah al-Islamiyyah.

Ash-Shiddiqi, Hasbi. 1975. Falsafah Hukum Islam. Jakarta. Bulan Bintang.
Aliyudin. Dasar-Dasar IImu Dakwah. Fakultas Dakwah Dan Komunikasi Uin Sgd Bandung. Jum'ah, Amin Abdul Azis. 2010. Fiqh Dakwah (terj.). Era Intermedia. Solo.

al-'Uqail, Ahmad bin Abdul Wahhab. 2003. Qul Hadzihi Sabili Ad'u ila Allah ala Bashirah. Mesir. Dar alKutub.

Poeradisastra, S.I. 1981. Sumbangan Islam kepada IImu d an kebudayaan Modern. Jakarta: Girimukti Pasaka.

Izzan, Ahmad. 2007. Metodologi Pembelajaran Bahasa Arab. Cet.II; Bandung: Humaniora.

Djamarah, Syaiful Bahri. 2008. Psikologi Belajar. Cet. II; Jakarta: PT. Rineka Cipta.

Atang Abd. Hakim dan Jauhari Mubarak. 2008. Metodologi Studi Islam. Bandung: Rosdakarya.

Rahmat, Jalaluddin. 1998. Retorika Modern Pendekatan Paraktis. Bandung: Remaja Rosdakarya.

Arifin, M. 1993. Psikologi Dakwah Suatu Pengantar Studi. Jakarta: Bumi Aksara.

A Shomad, Idris. 2004. Diktat IImu Dakwah. UIN Syarif Hidayatullah, Fakultas Dakwah dan Komunikasi: Jakarta. 
M.Munir dan Wahyu Ilahi, Manajemen

Dakwah. Cet. II; Jakarta: Kencana

Prenada Media Group.

Badrutamam, Nurul. 2005. Dakwah Kolaboratif Tarmizi Taher. Jakarta: Grafindo.

Abu Zaid Nasr Hamid. 2002. Tekstualitas

Alquran. Ed. Revisi; Yogyakarta: LkiS.

Arsyad, Azhar. 2004. Bahasa Arab dan Metode Pengajarannya. Cet.II; Pustaka Pelajar: Yogyakarta.

Kitab Tafsir Alquran Al-'Azhim, Ibnu Katsir, Jilid 2.

http://m.anwar-sanusi.abatasa.co.id

Mubarak, Ahmad. 2002. Dakwah Islam.

Cet. I; Bogor: Thariqul Izzah. 